\title{
Folate Receptor Alpha
}

National Cancer Institute

\section{Source}

National Cancer Institute. Folate Receptor Alpha. NCI Thesaurus. Code C39284.

Folate receptor alpha (257 aa, $\sim 30 \mathrm{kDa}$ ) is encoded by the human FOLR1 gene. This protein is involved in cellular import of folate, 5-methyltetrahydrofolate, and folic acid derivatives. 